\title{
Parental Education, Household Health, and Household Standard of Living: Evidence from Rural Cameroon ${ }^{1}$
}

\author{
Issidor Noumba ${ }^{1}$, Quentin Lebrun Nzouessah Feunke ${ }^{1}$ \\ ${ }^{1}$ Faculty of Economics and Management, University of Yaoundé II - Soa - Cameroon \\ Correspondence: Issidor Noumba, Associate Professor, Faculty of Economics and Management, University of \\ Yaoundé II - Soa - Cameroon.
}

Received: March 23, 2020

Accepted: May 25, $2020 \quad$ Online Published: June 23, 2020

doi:10.5539/ibr.v13n7p113

URL: https://doi.org/10.5539/ibr.v13n7p113

\begin{abstract}
Recent data show that social and economic conditions of rural dwellers are worsening in Cameroon. This paper estimates the link between parental education and household health. It also relates household health to household economic wellbeing (ECW), jointly education and health to ECW. Data employed are from a national survey conducted by the National Institute of Statistics in 2011. The unitary household economic model is the theoretical foundation. Empirical models specified are estimated using different methods. OLS is employed to estimate the link between education and ECW. One result on which the paper insists is obtained from a non-linear control function specification. Two salient results are highlighted. i) Education appears to be a significant determinant of household health. ii) Education and health are not perfect substitutes in the household utility function. These findings could guide policymakers in search for effective health and education programs aimed at improving rural economic wellbeing.
\end{abstract}

Keywords: parental education, household health, economic wellbeing, rural Cameroon

\section{JEL: I1, D1, R1}

\section{Introduction}

According to the World Health Organization (WHO, 2001), health is a thorough state of physical, mental and social comfort. Health can be affected by many observable and/or unobservable factors not strictly linked to a specific known disease. A large body of literature on the human capital theory contends that health is an important determinant of the individual, household and community wellbeing. A healthy individual is likely to be more productive than an individual suffering from poor health, meaning that health is a family/household and individual production factor (Grossman, 1982; Culyer and Newhouse, 2000; Mwabu, 2009, etc.). In other words, health seems to be a clear source of wealth and socioeconomic wellbeing (Woolf et al; 2015), or "health is wealth" (Ogunleye and Eriș, 2008, p. 110). Better health for all the household members may result in savings on medical expenditures. In particular, "parents make use of extra time accrue to them due to better health for their children and family to do extra work that fetches them money" (Tambi et al; 2014, p. 3). In some ways, the resources saved due to the better household's health status, will complement the individual's and household's income, soften their budget constraint, acquire more educational inputs, and, later on, improve on their social and economic wellbeing. These transmissions channels could be described as the health-wealth virtuous circle.

But to be always healthier, one needs to consume a bulk of costly inputs such as food, health and non-health services (Mwabu, 2009). Otherwise, an individual's or a family's health status may also be depending upon his educational capital. It is assumed that more educated individuals will earn higher income and be capable to purchase more health inputs, remain healthier and increase their economic and social wellbeing. However, the subject remains controversial due namely to a potential reciprocal causation between education and health.

Given their importance for the whole society, health and education have been included among top United

${ }^{1}$ One version of this paper was presented at the international workshop organized by the University of Dschang - CAMEROON on the $8^{\text {th }}$ and $9^{\text {th }}$ January 2018 . We thank all the participants for their comments that allowed us for improving on the quality of the paper. Nevertheless, all eventual errors are the responsibility of the sole authors. 
Nations Sustainable Development Goals (SDGs) through objectives 3 and 4 for health and education, respectively.

With regard to health, available data show that substantial progress have been made worldwide. For example, according to the WHO (2019), the under-five mortality rate came down from 77 deaths per 1000 living births in 2000 to 39 in 2017, while the number of deaths due to infectious diseases shrunk from 5.3 million people in 2000 to 4.3 million in 2016, etc. Likewise, the proportion of births under the supervision of a trained health personnel increased from 69 percent between 2006 and 2012 to 81 percent between 2013 and 2018 (United Nations, 2019). However, health still remains one major global challenge for policy makers, households, and individuals. Human health continues to be frequently threaten by numerous well-known and new diseases. For instance, 59.1 per thousand of the global population where at risk of malaria in 2017 (WHO, op. cit., p. 96). Today, the new Coronavirus (Covid-19) appears to be another new cause of global concern.

As for the educational outcomes, the situation seems somehow mitigated -as in the case of health outcomes. For instance, it is laudable to note that at a global level, the participation rate in early childhood education increased from 63 percent in 2010 to 69 percent in 2017 (United Nations, 2019). Unfortunately, "despite considerable progress in educational access and participation (years of steady growth in enrolment rates), non-proficiency rates remain disturbingly high while 262 million children and adolescents (6 to 17 years old) were still out of school in 2017" (United Nations, op. cit. p. 33).

Furthermore, progress have also been made on education and health in sub-Saharan Africa (SSA). But, this region is still lagging back compared with the global averages. In 2017, the world average of the participation rate in early childhood education cited above stood at 69 percent against only 42 percent in SSA. In this SSA region, many public and private schools continue to be lacking some basic elements required for quality education, namely trained teachers and sound facilities (United Nations, op. cit.).

After all, better outcomes in health and education worldwide seem to have been translated into global and African wellbeing. At a global level, extreme poverty has tremendously declined, since the share of the world's population living in extreme poverty decreased from 36 percent in 1990 to 10 percent in 2015. "More than one billion people have lifted themselves out of poverty over the past 25 years". In the same vein, the proportion of people living on less than $\$ 1.90$ a day in SSA has decreased from 45 percent in 2010 to 38 percent in 2018. But the situation in the region remains preoccupying since more than 56 percent of the world population who lived on less than $\$ 1.90$ a day in 2015 were found there. Besides, the number of people who lived on less than $\$ 1.90$ a day "has been climbing in recent years and is higher than the number of poor people in the rest of the world combined" (United Nations, op. cit. p. 32).

The International Monetary Fund (IMF, 2014) predicted an increasing GDP growth rates from 4.7 percent in 2013 to about 5 percent in 2014, and 5.25 percent in 2015. Unfortunately, these GDP growth rates seem not enough to significantly reduce poverty in SSA. In fact, the projections of the IMF seem to have been very optimistic since, according to the World Bank (2017), the GDP growth rate has fallen from 4.6 percent in 2012 to 3.0 percent in 2015 in SSA. Thus, to meet the challenges of better health, higher education outcomes, and lower poverty indices, it urges to speed up the rhythm of the wealth creation in order to significantly reduce the poverty incidence in sub-Saharan Africa.

The main objective of the present study is to investigate the links between education, health and household economic wellbeing in rural Cameroon. This main objective is attained in three steps.

(i) Estimating the link between household education and household health;

(ii) Estimating the link between household health and household economic wellbeing;

(iii) Deducing the joint effects of education and health on household economic wellbeing.

In fact, let's recognize that some progress have been made in the field of both health and education in Cameroon too. From 2015 to 2017, the under-five mortality rate shrunk from 19.7 deaths per 1000 living births to 17.4, while the malaria incidence slightly declined from 316 deaths per one thousand population to 304 . The gross enrollment ratio in the primary jumped from 99.6 percent between 2001 and 2007 to 119.16 between 2015 and 2017, and the pupil teacher ratio improved from 53.1 to 42.7 on the same period. The share of public expenditure on education was 16.5 percent in 2018, slightly above the 15 percent standard adopted by the international community at the Abuja conference in 2000 (African Development Bank, ADB, 2019).

The situation in both domains is still preoccupying when we come to rural zones of Cameroon compared with the urban areas. It goes without saying that, even in rural areas, notable progress have been obtained in the domains of health and education. But, the rural areas are worse off compared with urban areas. Concerning 
health, in particular, the under-five mortality rate is higher in rural areas (78 percent) than in urban areas (49 percent) against 36 percent in Yaoundé (the city capital). Likewise, the immunization rate of babies aged between 12 and 23 months stands at 67.7 percent and 85.4 percent, respectively in rural and urban areas. In rural regions, fertility rate increased from 6.1 in 2004 to 6.4 in 2011. The trend of total net school enrollment ratio is upward but lower in rural zones than in urban zones of Cameroon (INS, 2015a) ${ }^{2}$.

Let us insist on the fact that in spite of subsequent and perceptible efforts to build new health infrastructure and equipment, accessing the health services remains a nightmare for many Cameroonians even in urban areas. It is common knowledge that human and material resources related to health are concentrated in the urban areas of the country, namely Yaoundé and Douala, respectively political and economic capital. Public and private high standing hospitals and clinics, most general practitioners, and specialists are established in the two biggest cities of the country. Over the period 2009-2018, the country's density of medical doctors was less than one physician per 10,000 population! (WHO, 2019) Consequently, effective access to medical care is very difficult in many other urban and rural regions of the country, irrespective of the individual's and households' standard of living. From this point of view, rural dwellers in particular have serious difficulties to physically get access to the health centers and health services. They have to walk, very often to trek, on long distances and bad untarred roads to meet a surgeon, an orthopedist, an ophthalmologist, etc. The educational sector is facing the same types of difficulties, particularly, the uneven distribution of physical and human resources on the national territory.

Besides, access to some other basic social services is another challenge faced with by the rural dwellers of Cameroon. For instance, 17.1 percent of the rural household members' drinking water comes from unimproved pit, against 1.3 percent for urban areas (INS, 2015a). In one world like a thousand, living conditions in rural Cameroon appear to be really poor.

If we consider the household's well-being, we shall notice that, in Cameroon, the national situation seems to be improving over time. In particular, the national poverty incidence is, slowly, declining since $2001^{3}$. The poverty incidence calculated from the national monetary poverty line slightly decreased from 56.4 percent in 1996 , to 40.2 percent in 2001, 39.9 percent in 2007, and 37.5 percent in 2014 (INS, 2015b) ${ }^{4}$. For sure, poverty rates shrunk in urban zones (12.2 percent in 2007, and 8.9 percent in 2014). However, the situation worsened in rural regions were the poverty incidence rather increased from 52.1 percent in 2001, then to 55.0 percent in 2007, and 56.8 percent in 2014 (INS, 2015a). Thus, the trend in rural poverty seems to have been steadily increasing on the period. In other words, some education and health outcomes have been slowly improving in rural Cameroon, but this seems not to be translating into better living conditions. Then, paraphrasing Pritchett (1996), we can also ask: in rural Cameroon, where have "all the education and health gone"? Anyhow, we expect a strong link between education and health on the one hand, education and economic wellbeing on the other hand.

The government of Cameroon aims at reducing by one third the morbidity rate among the very poor and vulnerable population, by two thirds the under-five mortality, and three quarters the maternal mortality, especially in rural areas of the country by 2020 (Ministère de la santé publique (MINSANTE) (2018). In this context, putting forth the significant determinants of the household health status, for instance, could inform the public authorities of Cameroon on significant variables that can be used to effectively evaluate national health policy. Further, it could be very interesting to know if education and health outcomes jointly have significant effects on household economic wellbeing in rural Cameroon. We should not forget that Cameroon, a very poor and highly indebted country, has to meet multiple facets challenges, under a very binding budget constraint.

When we go through the WHO's (2001) definition of health given above, it appears that human health is essentially an individual phenomenon. This or that individual is in good or poor health. This is to say that the health status of an individual could be captured by a dichotomous variable (being in good health or in poor health). If an individual is in poor health, it is possible to check for what he or she is suffering from. The said individual may be suffering from malaria, intestinal worms, heart disease, congenital diseases, fatalities, etc. Then, one can investigate the profile of a particular disease in a community or at the national level using the individual (micro) or national (macro) information, etc. Aggregating the micro health indicators leads to macro indicators such as infant and under-five mortality rates, the morbidity ratio, etc.

\footnotetext{
${ }^{2}$ We have not been able to lay hand on updated data.

${ }^{3}$ It is about the monetary poverty measured from the national poverty line.

${ }^{4}$ The downward trend of poverty in Cameroon is confirmed when international poverty lines are used. The proportion of population living on less than $\$ 1.90$ shrunk from 29.3 percent in 2007 to 24 percent in 2014 (World Bank (2017)).
} 
We want to say that one important issue to consider is the pertinent indicator that should be chosen as a close proxy for the health status of an individual or a household. In this paper, we use the household's health status surrogated by the number of individuals who were sick, felt sick or sustained an injury 30 days before the interview. Then, the unit of analysis is the household. The unitary household economics model is the theoretical underpinning of the study. Econometric estimates indicate that education is a significant determinant of household health. Furthermore, both education and health jointly have to be complemented with other variables to significantly improve on economic well-being in rural Cameroon.

The remainder of the paper is as follows. Materials and methods are presented in Section 2. Theoretical foundation of the study is described in Section 3. Section 4 puts forth the results and discussion of empirical results, while section 5 concludes the paper.

\section{Material and Methods}

\subsection{Literature}

Studying the link between education and health, health and standard of living, and the joint effects of education and health on the household's economic wellbeing, requires the selection of pertinent quantitative or qualitative measures of the variables at stake. Strauss and Thomas (1998, pp. 790 - 798) discussed this matter and critically reviewed a series of health indicators with their respective strengths and weaknesses. The two authors mentioned also the choice of the unit of analysis, namely, individuals' health (adults, adolescents, infant or children) or households' health. Quite a number of researchers have addressed the child health captured by diverse indicators. For instance, Rosenzweig and Schultz (1989), Grossman and Joyce (1990), Joyce (1994), Rosenzweig and Zhang (2006), Gan and Gong (2007), Mwabu (2009), used birth weight to study child health, whereas Baye and Fambon (2010) used weight-for-age Z score. Barrow and Malamud (2015) dealt with early childhood captured by height. Anttila-Hughes et al; (2018) pointed out the role of a multinational company marketing of infant formula on infant deaths in low and middle-income countries.

In the literature dedicated to the link between education, health and wellbeing, many indicators have been used to capture education. Curtler and Lleras-Muney (2006), like a lot of authors, captured education outcomes by the number of years of schooling. In Buckles et al; (2013), the proxy of the education outcome chosen is the college completion rates. Heckman et al; (2014) used the cognitive and socio-emotional endowments, enrollment and graduation. In Barrow and Malamud (2018), education is a constructed years of schooling, etc.

Anyhow, irrespective of the indicators utilized and the unit of analysis, many studies have often concluded that education is significantly and positively associated with health. For example, Aly and Grabowski (1990) was concerned with the link between education and child mortality in Egypt, controlling for some socioeconomic and "environmental" variables, and came to the same results. Lleras-Muney (2005) utilized mortality as an adult health outcome and demonstrated that education has a positive and significant effect on health in the United States. Likewise, Heckman et al; (2014), noticed that the positive correlation between schooling and health (infant, child or adult) is a well-established finding. Adams (2002), Arkes (2003), Grossman (2005), Curtler and Lleras-Muney (2006, 2010a, 2010b, and 2012), Clark and Royer (2010), Bleakly et al; (2013), Cesur et al; (2014), Huang (2015), and many other authors came to the same conclusion, studying the adult health. Using a variety of data sets from two countries, Curtler and Lleras-Muney (2010b), for example, showed that knowledge and measures of cognitive ability have to do with differences in health behaviors. Using different methods and different settings, Grossman (2008), Conti et al; (2010), Baye and Fambon (2010), and Zheng (2017) came also to the same conclusion.

Manifestly, education seems really to matter to health. The well-known conventional wisdom is that education leads to better jobs and higher income. With a real high income, it is easier to access better health facilities, buy more health services, obtain better preventive care, and reduce risk and frequency of falling sick, increase vitality, longevity, and expect better school success for future generations (see also Robert Wood Johnson Foundation, 2013).

However, Meghir et al; (2013), in their study pertained to Sweden, obtained some results contradicting those found in the studies reviewed so far. Heckman et al; (2016, p. 46), analyzing the National Longitudinal Sample of Youth (NLSY79) data, discovered also that: "there are no causal effects of college graduation for low-ability persons". A recent review of the literature on the subject presented by Corman et al; (2017) indicates clearly that the debate on this matter is far from being closed. In fact, Malamud et al; (2018), in their study on Romania, arrived at the same conclusion. These authors indicated that "the schooling reform led to significant increases in years of schooling and changes in labor market outcomes but did not affect mortality, or self-reported health". 
Surely, assessing the relationship between education and health is a pertinent subject acknowledged in the literature, But, Cesur et al; (2014) observe that "the overwhelming majority of research to identify the health returns to education has been done using data from developed countries".

Let's keep in mind that a bulk of literature has been also dedicated to the causal effect of health on education, as well as to the link between education and health. However, the debate is still raging. If Behrman (1996, p. 23) drew our attention on the fact that the strong link between health and education does "not necessary imply causality", Walker et al; (2005) kept reporting strong causal links between child health and educational achievements in Jamaica. According to the American Public Health Association (APHA, 2018, p. 3), "students who use School-Based Health Centers (SBHC) have better grade point averages and attendance compared to students who do not use such centers. As students' health and emotional wellbeing improves, so does their academic performance". Thus, there seems to be a clear reversal causation between health and education, one problem that we are going to deal with in the specification of the structural model estimated in this study.

Finally, the link between education, health, and economic outcomes is another theme of interest in this study. Ogunleye and Eris (2008, p. 109), utilized OLS and granger causality methods to estimate time series data collected on Nigeria and Turkey. Their results show that "while health human capital is an important determinant of growth in Turkey, no relationship between human capital and growth could be established for Nigeria". They contended that the difference in growth rates between the two countries stems from the fact that the education system in Turkey is better than that of Nigeria.

This study intends to bring a stone to the construction of the literature devoted to the education and health nexus, the link between education, health and wealth, in utilizing data coming specifically from rural Cameroon. Contrary to the studies reviewed so far, the health indicator chosen is the number of cases of sickness registered in the household, the unit of the analysis. Another minor value of the paper is the estimation of joint effects of education and health on households' economic well-being, that was not done, namely by Ogunleye and Eris (2008). In their study on education, health and well-being, Baye and Fambon (2009) analyzed the joint effects of health and education on household economic wellbeing, but they focused on child health captured by the weight-for-age z-score (WAZ), and kept aside the rural areas of Cameroon. Later on, Baye and Fambon (2010) examined the link between parental education and child health, but they used older data coming from the Cameroon Household Consumption Survey data collected by INS in 2001. Tambi et al; (2014) used the focus group design method to link child health, maternal status on the labor market and household property in Cameroon. Their approach was non-technical since they refer to "what people say on different health domains", without targeting a specific child health outcome, and neglecting the rural Cameroon.

Table 1. Distribution of clusters and households selected into the sample

\begin{tabular}{|c|c|c|c|c|c|c|c|}
\hline \multirow[b]{3}{*}{ Region } & \multicolumn{5}{|c|}{ Number of Clusters } & \multicolumn{2}{|c|}{ Households Selected } \\
\hline & \multicolumn{2}{|c|}{ Urban } & \multicolumn{3}{|r|}{ Rural } & \multirow{2}{*}{$\begin{array}{l}\text { Urban } \\
\text { (7) }\end{array}$} & \multirow{2}{*}{$\begin{array}{l}\text { Rural } \\
(8)\end{array}$} \\
\hline & $\begin{array}{l}\text { Total } \\
(2)\end{array}$ & $\begin{array}{l}\text { Selected } \\
\text { (3) }\end{array}$ & $\begin{array}{l}\text { Total } \\
(4)\end{array}$ & $\begin{array}{l}\text { Selected } \\
(5)\end{array}$ & $\begin{array}{l}\text { Average households per } \\
\text { cluster (6) }\end{array}$ & & \\
\hline Adamaoua & 321 & 19 & 482 & 25 & 175 & 418 & 700 \\
\hline Center & 412 & 18 & 1,153 & 30 & 131 & 396 & 840 \\
\hline Douala & 1,580 & 54 & 31 & 0 & 131 & 1,188 & 0 \\
\hline East & 270 & 17 & 570 & 26 & 157 & 374 & 728 \\
\hline Far North & 678 & 15 & 2,458 & 44 & 144 & 330 & 1,232 \\
\hline Littoral & 450 & 30 & 268 & 11 & 151 & 660 & 308 \\
\hline North & 325 & 15 & 1,013 & 36 & 186 & 330 & 1,008 \\
\hline North West & 513 & 18 & 1,286 & 32 & 135 & 396 & 896 \\
\hline South & 178 & 15 & 455 & 24 & 143 & 330 & 672 \\
\hline South West & 485 & 18 & 814 & 29 & 169 & 396 & 812 \\
\hline West & 876 & 24 & 1,216 & 28 & 156 & 528 & 784 \\
\hline Yaoundé & 1,412 & 52 & 71 & 0 & 151 & 1,144 & 0 \\
\hline NATIONAL & 7,500 & 295 & $\mathbf{9 , 8 1 7}$ & 285 & 152 & 6,490 & 7,980 \\
\hline
\end{tabular}

Source: National Institute of Statistics, EDS-MICS (2012), Appendix A1 and A3, pages 374 and 75) ${ }^{5}$.

\footnotetext{
${ }^{5}$ For details on the survey methodology, see INS (2012, September, Appendix A), report free on line.
} 


\subsection{Data}

The data utilized in this study come from the National Institute of Statistics (INS) of Cameroon that carried out a national Health and Demographic Survey and published the report in 2012. 580 clusters were selected over the whole national territory, of which 295 in urban areas and 285 in rural areas. 14,470 households were selected, 6,490 in urban areas and 7,980 in rural zones. Table 1 on the previous page presents the regional distribution of clusters and households samples selected. Yaoundé and Douala were singled out, being essentially urban settings.

Table 1 shows that 7,980 households, the basic sample, were selected in rural areas. 3,307 male households' heads were successfully interviewed, against 3,189 female, meaning that 484 households' heads are missing in the sample. The average households per cluster is 184 for the urban and 152 for the rural zones, while the general average stands at 166 households.

It was a stratified sampling that permitted to collect data on different aspects of the household: health, household size $^{6}$, housing characteristics, hygiene, sanitation, individual information on education, age, sex, etc. Household's economic wellbeing was calculated in combining housing characteristics and household asset endowments. It is an index constructed from many items chosen through the principal component analysis $\operatorname{method}^{7}$. Household health, household education and household economic wellbeing are the exogenous variables. Table 2 describes the variables shortlisted for the regressions.

Table 2. Descriptive statistics

\begin{tabular}{|c|c|c|c|}
\hline Variables & $\begin{array}{l}\text { Number of } \\
\text { observations }\end{array}$ & Mean & $\begin{array}{l}\text { Standard } \\
\text { deviation }\end{array}$ \\
\hline \multicolumn{4}{|l|}{ Panel A: Outcome variables } \\
\hline Health (defined above) & 1,518 & 1.3208 & 0.6777 \\
\hline Household head's education ( $1=$ has attended any school level and 0, no) & 7,503 & 0.5051 & 0.5000 \\
\hline Household size (defined above) & 7,503 & 5.376 & 3.668 \\
\hline Household head's sex $(1=$ male and 0, no $)$ & 7,503 & 0.7616 & 0.4260 \\
\hline Household head's age (number of years) & 7,501 & 48.6464 & 16.5919 \\
\hline Household head's age squared & 7,501 & 2641.733 & 1727.745 \\
\hline Marital status (Marital_stat1 (= bachelor and 0, no) & 7,503 & 0.0641 & 0.2449 \\
\hline Marital status (Marital_stat2 $(1=$ married and 0, no $)$ & 7,503 & 0.7095 & 0.4539 \\
\hline Marital status (Marital_stat3 $(1=$ divorcee and 0, no $)$ & 7,503 & 0.0579 & 0.2337 \\
\hline Marital_stat4 $(1=$ widow and 0, no $)$ & 7,503 & 0.1598 & 0.3664 \\
\hline \multicolumn{4}{|l|}{ Panel B: Instruments for literacy and sample selection } \\
\hline Owns the land cultivated $(1=$ yes and 0, no $)$ & 7,501 & 0.8924 & 0.3098 \\
\hline Agricultural land owned by the household (acre) & 6,686 & 88.9324 & 219.6128 \\
\hline Distance to the source of drinking water (kilometer) & 7,476 & 1.9942 & 6.95269 \\
\hline Time to the drinking water source (minutes) & 7,448 & 92.0443 & 26.2339 \\
\hline Type of toilet facility $(1=$ improved and 0, no $)$ & 7,495 & 0.16035 & 0.4689 \\
\hline Sharing toilets with other households $(1=$ yes and 0, no $)$ & 6,703 & 0.2794 & 0.4487 \\
\hline \multicolumn{4}{|l|}{ Panel C: Controls for un-observed variables } \\
\hline Predicted education residual & 6,644 & 0.0266 & 0.6939 \\
\hline Interaction between education and its residual & 6,644 & 0.0010 & 0.0951 \\
\hline Inverse of the Mills ratio & 6,644 & 0.8345 & 0.4197 \\
\hline \multicolumn{4}{|l|}{ Panel D: Variables for the economic well-being generation function } \\
\hline Primary education (education $1 ;$ yes $=1$ and 0, no) & 7,503 & 0.3317 & 1.3530 \\
\hline Secondary education (education $2 ;$ yes $=1$ and 0, no) & 7,503 & 0.1547 & 0.6984 \\
\hline Secondary high education (education 3 ; yes $=1$ and 0, no) & 7,503 & 0.1243 & 0.8449 \\
\hline University education (education 4 , yes $=1$ and 0, no) & 7,503 & 0.0392 & 0.4882 \\
\hline Economic wellbeing index (EWB_Index) & 6,925 & 11.7625 & 0.4775 \\
\hline
\end{tabular}

Source: Constructed by the authors with data extracted from EDS (INS, 2012) data set.

Let us say a few words on some statistics presented on 3 out of 4 panels of Table 2.

${ }^{6}$ The number of persons regularly living under the same roof, and the authority of the household head.

${ }^{7}$ Details on the methodology used to construct the household economic wellbeing variable is described in the report on Health and Demographic Survey, produced by INS (2012, p. 23-25). 
Panel A: It can be seen from the Table that more than one household member (1.3208) felt sick, were sick, or sustained an injury 30 days before the interview ${ }^{8}$. Around 50 percent of the household heads are illiterate, since they did not attain any school level. Furthermore, the average household size is more than 5 individuals. The household heads are relatively young, since around 71 percent are less than 50 years old. More than 70 percent of the household heads are married, and nearly 16 percent widows. Above 76 percent of the household heads are males.

Panel B: It comes out of this panel that around 89 percent of the households owned the land that they cultivate and the land area is less that one hectare. The distance to the closest drinking water source is far (almost $2 \mathrm{Km}$ ) and it takes around one hour and a half to get there. Only 16 percent of the households use improved toilet facilities, whereas 28 percent share theirs.

Panel D: From this panel, we can see that the education level of rural households' heads of Cameroon remained relatively low, which confirms the figure on school attendance (Panel A). In fact, 33 percent of the household's heads completed primary school education, 16 percent secondary school (college), 12 percent secondary high school, and only 4 percent University.

\section{Theory}

\subsection{Theoretical Underpinning}

We use the unitary household model of the "new household economics" where decisions relating to the health and education issues are made by the household heads ${ }^{9}$. It is assumed that health belongs to the set of arguments that enter the household utility function maximized by the household head. Let's not forget that we are dealing with the rural Cameroon that remains characterized by a great dose of conservatism in behaviors. Thus, the theoretical model driving the study relies on "an obedience-based "authoritarian" parenting style" (Doepke et al. 2019 , p. 2). Then, in line with Heller (1982), we specify the utility function $U$ for any household $i$ symbolized by $U_{i}$ with $X_{i}$ and $H_{i}$ being the arguments in Equation 1 that follows.

$$
U_{i}=U\left(X_{i}, H_{i}\right)
$$

$X_{i}$ is the vector of goods not related to health. $H_{i}$ is the vector of goods closely related to health that yield utility to the household head and affect the household health status (practice of sport, alcohol consumption, attitude toward smoking, use of mosquito nets, prevention behavior, etc.). To be always healthier, the household has to maximize the health production function given by Equation (2).

$$
H_{i}=H\left(Y_{i}, Z_{i}, \varepsilon_{i}\right)
$$

$Y$ is made up of individual and household characteristics (age, sex, wealth, nutrition, asset endowment, education, etc.). $Z$ comprises the household environment (sanitation system, access to potable water, washing hands practice, etc.), and $\varepsilon$, a vector of unobserved variables such as full of joie de vivre, happiness, household head innate endowments, etc. Combining Equations (1) and (2) leads to a "new" household utility function specified in Equation (3).

$$
U_{i}=U\left(X_{i}, Y_{i}, Z_{i}, \varepsilon_{i}\right)
$$

Equation (3) shows that the household utility function depends upon non-health goods $(X)$, the individual and household characteristics $(Z)$. We assume that the non-health goods $X$ contribute to improve household utility but has no direct effect on the household health. Those goods maybe the father's hobby or the mother's hair-style, for example. The household head maximizes the household utility function (3) subject to the household budget constraint $(R)$ specified in Equation (4).

$$
R=X P_{x}+Y P_{y}+Z P_{z}
$$

Using the maximization process that combines Equations (3) and (4), yields the health demand functions for $\mathrm{X}, \mathrm{Y}$, and $\mathrm{Z}$ that we specify as follows.

$$
\begin{aligned}
& X=d_{x}\left(P_{x}, P_{y}, P_{z}, \varepsilon\right) \\
& Y=d_{y}\left(P_{x}, P_{y}, P_{z}, \varepsilon\right)
\end{aligned}
$$

\footnotetext{
${ }^{8}$ In a previous survey, the Ministry of Water and Energy (MINEE) (2013) found also that, in rural Cameroon, in 65 percent of rural households, 0 to 12 cases of sickness were registered two weeks before the interview.

${ }^{9}$ This theoretical underpinning has been applied in many studies dealing with child health. Example, Handa (1999) and Mwabu (2009).
} 


$$
Z=d_{z}\left(P_{x}, P_{y}, P_{z}, \varepsilon\right)
$$

The effects of changes in prices of the three goods on the household health status can be derived from Equations (5) through (7). In fact, the differential of Equation (2) above shows that a change in the household health status can be expressed as follows.

$$
d H=\frac{d H}{d Y} \times d Y+\frac{d H}{d Z} \times d Z+\frac{d H}{d \varepsilon} \times d \varepsilon
$$

Where $\mathrm{dH} / \mathrm{dY}, \mathrm{dH} / \mathrm{dZ}$, and $\mathrm{dH} / \mathrm{d} \varepsilon$ are marginal products of health inputs $\mathrm{Y}, \mathrm{Z}$ and $\varepsilon$ respectively.

The change in the household health status can be related to changes in respective prices of health inputs when specified as follows.

$$
\begin{aligned}
& \frac{d H}{d P_{x}}=\frac{d H}{d X} \times \frac{d Y}{d P_{x}}+\frac{d H}{d Z} \times \frac{d Z}{d P_{x}}+\frac{d H}{d \varepsilon} \times \frac{d \varepsilon}{d P_{x}} \ldots \\
& \frac{d H}{d P_{y}}=\frac{d H}{d y} \times \frac{d Y}{d P_{y}}+\frac{d H}{d Z} \times \frac{d Z}{d P_{y}}+\frac{d H}{d \varepsilon} \times \frac{d \varepsilon}{d P_{y}} \ldots \\
& \frac{d H}{d P_{z}}=\frac{d H}{d z} \times \frac{d Y}{d P_{z}}+\frac{d H}{d Z} \times \frac{d Z}{d P_{z}}+\frac{d H}{d \varepsilon} \times \frac{d \varepsilon}{d P_{z}} \ldots \ldots
\end{aligned}
$$

We assume that $d \varepsilon / d P_{i}=0$, for all $X, Y$, and $Z$, implying that in Equations (9), (10), and (11), $d H / d \varepsilon x()=0,. \varepsilon$ being a random variable unrelated neither to $P_{x}$, nor to $P_{y}$ and $P_{z}$.

It comes out of expressions (9), (10), and (11) that prices of commodities $X, Y$, and $Z$ are correlated with the household health $H$. The signs and magnitudes of these correlations depend on the sizes of changes in demand for health inputs provoked by the price changes and the size of the marginal products of $X, Y$, and $Z$.

\subsection{Empirical Models}

\subsubsection{Linking Household Education to Household Health}

Let us recall that health $(H)$, is the number of households' members who felt sick, were sick or sustained an injury 30 days before the interview. Thus, $H$ is a counting variable. What we call household education is the household head's education (HHE). The causal mechanism going on is represented by the determination of the relationship between household health $(H)$ and household head's education, taking into account other covariates.

Like in Wooldridge (2002), Ajakaiye and Mwabu (2007), the empirical specifications of the link between household health and household education is specified by these simultaneous equations.

$$
\begin{aligned}
& H=H\left(x, H H E, \varepsilon_{1}\right) \ldots \\
& H H E=H H E\left(x_{1}, \varepsilon_{2}\right) \\
& I F S=I F S\left(x_{2}, \varepsilon_{3}\right) \ldots
\end{aligned}
$$

Equation (12) depicts the link between household health $(H)$ and household head education $(H H E), x$ being a vector of control variables.

Equation (13) captures the link between HHE and $\mathrm{x}_{1}$, a set of control variables. IFS is the function for selection of the $x_{2}$ into the sample. IFS $=1\left(x_{2} \beta_{\text {ifs }}+\varepsilon_{3}\right)>0 \Leftrightarrow H$ is unobserved if IFS $\leq 0$, and $H=1$ if IFS $>0$, meaning that $H$ is observed.

Let $\beta_{H}$, be the derivative of $H$ proportionate to $x ; \gamma$, the derivative of $H$ proportionate to $H H E$;

$\beta_{\mathrm{HHE}}$, the derivative of $H H E$ proportionate to $x_{1}$, and $\beta_{i f s}$ the derivative of IFS proportionate to $x_{2}$.

In the system of Equations (12) - (14), $H$ and $H H E$ are defined above; $x$ is a vector of exogenous variables comprising $x_{1}$, the explanatory variables that belong to the household health production function and a vector of instrumental variables $x_{2}$, those supposed to affect household head's education but have no direct effect on the household health; $\beta$ and $\gamma$ are parameters to be estimated; $\varepsilon_{1}, \varepsilon_{2}$, and $\varepsilon_{3}$ are the error terms.

Two competing hypothesis could be formulated. $\mathrm{H}_{0}: \gamma=0$, meaning that household head's education should not 
have a direct effect on household health. The alternative hypothesis is $H_{1}: \gamma>0$, meaning that household head's education complement with other inputs to affect household health (spouse's education, health inputs consumed, better health and hygiene practices, etc.). This is the complementary hypothesis. But, $\gamma$ may also be negative showing, for example, that other variables, such as easier access to quality health infrastructure, public campaigns and actions for awareness on hygiene practices, etc., are likely to act at the place of the household head's education to impact the household health. This is the substitution hypothesis.

Equation (12) is the implicit structural health production function. We must not forget that there may be a reverse causation in this function because education could be significantly linked to some relevant household health inputs. If that was the case, OLS would not yield consistent estimates of Equation (12). Then, we use the maximum likelihood method to estimate Equation (12), the outcome equation that allows the correction of structural parameters for biases coming from endogeneity raised here. Appeal will be made to instrument variables that do not belong to the outcome Equation but correlate with the household head's education, the main endogenous variable at stake, not forgetting other control variables. Thus, Equation (13) has been explicitly specified as the linear projection of the potential endogenous variable $(H H E)$ on the whole exogenous variables $x$, $(x=x 1+x 2)$.

Equation (14) is the Probit model of sample selection. Because all the households interviewed did not provide for all the necessary information during the interview, namely on the household health status, they are not integrated in Equation (12). Equation (14) allows for correction for sample selection bias in the estimated parameters (see, for example, Heckman (1976, 1979), Mwabu (2009)). The correction factor derived from Equation (14) is the inverse of Mills ratio (MILLSH) (Heckman, 1979).

Up to now, we have raised the problem of potential endogeneity, as well as the non-linear interactions of unobservable variables with the household health inputs, the sample selection bias, and complementary or substitution behaviors. That is why, on the steps of Garen (1984), Wooldridge (1997), Card (2001), Mwabu (2009), and Baye and Fambon (2009), Equation (12) can be rewritten to include a control function that, linearized, becomes.

$$
H=a_{0}+x_{1} \beta+\gamma H H E+a_{1} \widetilde{\varepsilon_{2}}+\mu\left(\widetilde{\varepsilon_{2}} \times H H E\right)+\zeta M I L L S H+\eta_{1}
$$

In Equation (15), $\widetilde{\varepsilon_{2}}$ is the fitted residuals of $H H E$ derived from Equation (13); ( $\left.\widetilde{\varepsilon_{2}} \times H H E\right)$ is the interaction of the fitted education residual with actual (observed) household head's education; MILLSH is the Mills inverse ratio, obtained from the sample selection (Equation (14)); $\eta_{1}$ is a composite error term comprising $\varepsilon_{1}$ and $\varepsilon_{2}$ of Equations (12) and (13). We assume that $\eta_{1} \sim N(0, \sigma) ; a_{0}, a_{1}, \beta, \gamma, \mu$, and $\zeta$ are parameters to be estimated.

It is worth noting that Equation (15) does not contain the vector of instruments for education $\left(x_{1}\right)$. The terms $\left(\widetilde{\varepsilon_{2}}\right.$, $\left(\widetilde{\varepsilon_{2}} \times H H E\right)$ ), and (MILLSH) in Equation (15) are the control function variables used to control for the effects of unobserved factors and non-randomness capable to affect the structural parameters estimated. The fitted residual $\widetilde{\varepsilon_{2}}$ of education indicated above serves as the control for unobservable variables that correlate with the household education (HHE).

In order to correctly interpret the estimated parameters of the models specified (Equations (12) - (14)), the effects of the endogenous inputs and the sample selection rule on household health are to be identified. The instrumental variables technique is utilized for this purpose. In fact, we know that instrumental variables (IV) methods are employed in linear regression models that takes the form $Y=X \beta+\mu$, and where violations of the zero conditional mean assumption $(E[\mu \mid X]=0)$ is encountered. To rely on these methods, we have to make sure that appropriate instruments are available to identify the model. Exclusion restrictions are generally used for this purpose. But $Z$, the instruments chosen have to: (i) Satisfy orthogonality condition, i.e. $(E[u \mid Z]=0)$; (ii) be strongly correlated with $X$; and, (iii) be properly excluded from the model, so that their effect on the response variable is only indirect. One understands why it is not an easy task to lay hand on appropriate instruments that satisfy all the three conditions. The Hansen's (1982) method came to our rescue to solve the problem in view of appraising the robustness of the results reached at.

\subsubsection{Linking Household Health to Household Economic Wellbeing}

It goes without saying that household health is very important to the household economic and social comfort. The household, as a unit, feels uncomfortable even when one of its members is uncomfortable. In fact, household health matters much both to the present and future household human capital. Healthier households may not be wealthier households, but in healthier households, members are better prepared to snatch any opportunity to be in bloom (reading, regular practice of sport, peace of mind or travel, for instance). Besides, as Baye and Fambon 
(2009, p. 12) put it, "good health engenders potential household savings on medical expenditures and releases extra-time to adult household members to take more advantage of labor market opportunities". Like that, household health can be considered as an important argument of the household utility function. In the rural regions of Cameroon where people rely much on their physical power, healthy family members have more energy to farming larger land superficies, harvest more, sell more, earn more, and be in position to purchase a radio set, a new TV set, a drawing room suit, etc., all the stuff that can contribute to improve on their economic and social wellbeing. Therefore, we expect the household health to be correlated with omitted inputs that enhance household wellbeing. Let us specify the causal relationship between the household economic wellbeing and household health like this (Equation (16)).

$$
E C W=\psi y+\omega \dot{\mathrm{H}}+\mu 2 \ldots
$$

In Equation (16), $E C W$ is already defined; $\dot{H}$ is the number of the household members who were sick, felt sick or sustained an injury 30 days before the interview, predicted from the estimates of Equation (15); $y$ is a vector of exogenous variables that may impact the household economic wellbeing; $\psi$ and $\omega$ are additional parameters to be estimated, and $\mu_{2}$, the well-known error term. We guess that using the household predicted health will solve the potential problem of endogeneity of household health in the $E C W$ production function.

Again, two exclusive hypothesizes are considered: $\mathrm{H}_{0:} \omega=0$. This hypothesis means that household health has no effect on the household economic wellbeing. The alternative hypothesis is $\mathrm{H}_{1}: \omega>0$. In this hypothesis, we contend that household health affects the household ECW trough the mechanisms of transmission explicitly described by Baye and Fambon (2009, p. 13). But $\omega$ could also be inferior to 0, portraying negative effects of household health on household economic wellbeing. The gains acquired from better education are not translated into increasing household income, maybe because the private returns to education is nil (unemployed educated), inferior to the marginal cost of education (under-employed), or oriented towards leisure or risky health behaviors, for example. Besides, a household head with higher income could adopt risky behaviors like smoking or drinking alcohol that may endanger his health and affect the household economic wellbeing.

\section{Results and Discussion}

These results are going to be presented in the following order. $i$ ) linking household education to household health; ii) estimating the household economic wellbeing production function; iii) Deducing the estimated joint effects of education and health on the household economic wellbeing.

\subsection{Linking Household Education and Household Health}

May we recall that in the model estimated (Equation 15), education (literacy) is a dichotomous variable (being literate or no). Table 3 below displays estimates of the structural forms of the household health production function of the entire sample under different assumptions. Column (1) presents results of maximum likelihood (ML) estimates of the structural parameters of Equation 15; Columns (2) and (3) are the joint maximum likelihood estimates of the Heckman selection model of the structural parameters, correcting for potential sample selection bias, respectively; Column (4) is the first-stage least squares estimates of the reduced form of the literacy equation; column (5) is the General Method of Moment (GMM) estimates of the structural parameters accounting for potential endogeneity (the data on household health have the form of Poisson law (counting)); Columns (6) and (7) are control functions estimates. Column (6) is the 2SLS estimates correcting for potential sample selection and Column (7) the 2SLS estimates correcting for both potential sample selection and heterogeneity captured by the non-linear interaction term.

With regard to the link between education and health, the results displayed on columns (1) to (6) of Table 3 indicate that the coefficients attached to education (literacy) are positive and significant. Manifestly, these results are not consistent because of the nature of the household health indicator chosen. In fact, these results are indicating that being a literate household head significantly increases odds of having a higher number of cases of sickness in the household 30 days before the survey. These inconsistent findings may be due to the fact that the methods used to estimate the coefficients of the model under corresponding hypothesis are infested with the endogeneity, the reversal causation, un-observables (sample selection), and instrument variables problems. Infested with all these problems, coefficients estimated may be biased up or downward. This is why we are going to comment only on the results reported in column $(7)^{10}$.

${ }^{10}$ The control function method used to estimate the parameters is supposed to correct all these deficiencies. 
Table 3. Estimation of the household health production function under different assumptions

\begin{tabular}{|c|c|c|c|c|c|c|c|}
\hline \multirow{3}{*}{\begin{tabular}{|l|}
\multicolumn{1}{|c|}{ Methods } \\
Variables \\
\end{tabular}} & \multirow{3}{*}{$\begin{array}{l}\text { ML } \\
\dot{\mathrm{H}} \\
(1)\end{array}$} & \multicolumn{2}{|c|}{ Heckman selection (ML) } & \multicolumn{2}{|l|}{ IV (GML) } & \multirow{2}{*}{\multicolumn{2}{|c|}{$\begin{array}{l}\text { Control functions } \\
\mathrm{H}\end{array}$}} \\
\hline & & H reported & $\mathrm{H}$ & Education & $\mathrm{H}$ & & \\
\hline & & (2) & (3) & (4) & (5) & (6) Linear & (7) Non linear \\
\hline $\begin{array}{l}\text { Household head's } \\
\text { education } \\
\text { (Literacy) }\end{array}$ & $\begin{array}{l}0.0164 * * * \\
(0.0302)\end{array}$ & - & $\begin{array}{l}0.0164 * * \\
(0.0054)\end{array}$ & - & $\begin{array}{l}0.0159 * * \\
(0.0035)\end{array}$ & $\begin{array}{l}.1888 * * * \\
(0.0228)\end{array}$ & $\begin{array}{l}-0.4288 * * * \\
(0.0217)\end{array}$ \\
\hline $\begin{array}{l}\text { Household head's } \\
\text { sex }(1=\text { Male, } 1 \\
\text { Female })\end{array}$ & $\begin{array}{l}0.1374 \\
(0.5644)\end{array}$ & $\begin{array}{l}0.2699 * * * \\
(0.6546)\end{array}$ & $\begin{array}{l}0.1374 \\
(0.2744)\end{array}$ & $\begin{array}{l}-0.5463 * * * \\
(0.7838)\end{array}$ & $\begin{array}{l}-0.0011 \\
(0.0423)\end{array}$ & $\begin{array}{l}-0.8428^{*} \\
(0.3666)\end{array}$ & $\begin{array}{l}-0.0355^{* * * *} \\
(0.1203)\end{array}$ \\
\hline Household Size & $\begin{array}{l}0.0345 * * * \\
(0.0056)\end{array}$ & $\begin{array}{l}0.0588^{* * * *} \\
(0.0098)\end{array}$ & $\begin{array}{l}0.3451 * * * \\
(0.0040)\end{array}$ & $\begin{array}{l}-0.0077 \\
(0.0084)\end{array}$ & $\begin{array}{l}0.0336^{* * * *} \\
(0.0047)\end{array}$ & $\begin{array}{l}0.0337 \\
(0.0248)\end{array}$ & $\begin{array}{l}0.077^{* *} \\
(0.0106)\end{array}$ \\
\hline $\begin{array}{l}\text { Household head's } \\
\text { age }\end{array}$ & $\begin{array}{l}0.0012 \\
(0.0081)\end{array}$ & $\begin{array}{l}-0.034 * * \\
(0.0150) \\
\end{array}$ & $\begin{array}{l}0.0012 \\
(0.0042)\end{array}$ & $\begin{array}{l}0.0128 \\
(0.0114)\end{array}$ & $\begin{array}{l}0.0062 \\
(0.0052)\end{array}$ & $\begin{array}{l}-0.0105 \\
(0.0353) \\
\end{array}$ & $\begin{array}{l}-0.0064 * * \\
(0.013)\end{array}$ \\
\hline $\begin{array}{l}\text { Household Head's } \\
\text { age squared }\end{array}$ & $\begin{array}{l}-2.24 \mathrm{e}-06^{*} \\
(0.0007)\end{array}$ & $\begin{array}{l}0.00070^{*} \\
(0.00015) \\
\end{array}$ & $\begin{array}{l}-2.97 \mathrm{e}-06^{*} \\
(0.00005)\end{array}$ & $\begin{array}{l}-0.0003^{*} \\
(0.0001)\end{array}$ & $\begin{array}{l}-0.00005^{*} \\
(0.0005)\end{array}$ & $\begin{array}{l}0.0005 \\
(0.0003)\end{array}$ & $\begin{array}{l}0.0001 \\
(0.0001)\end{array}$ \\
\hline Marital status1 & $\begin{array}{l}0.0044 * * \\
(0.0152)\end{array}$ & $\begin{array}{l}0.1345 * * \\
(0.0466) \\
\end{array}$ & $\begin{array}{l}0.0044 * * \\
(0.004)\end{array}$ & $\begin{array}{l}-0.3129 \\
(0.1508) \\
\end{array}$ & $\begin{array}{l}0.0738^{* * * *} \\
(0.0475)\end{array}$ & $\begin{array}{l}1.0534 * * \\
(0.3615) \\
\end{array}$ & $\begin{array}{l}0.4299 \\
(0.2961)\end{array}$ \\
\hline Marital status2 & $\begin{array}{l}-0.0001 \\
(0.0011)\end{array}$ & $\begin{array}{l}-0.0235^{\text {**** }} \\
(0.0052)\end{array}$ & $\begin{array}{l}-0.0001 \\
(0.00013)\end{array}$ & $\begin{array}{l}-0.1544 * * * \\
(0.0803)\end{array}$ & $\begin{array}{l}-0.0052^{*} \\
(0.0030)\end{array}$ & $\begin{array}{l}0.1191 \\
(0.0833)\end{array}$ & $\begin{array}{l}0.3584 * * \\
(0.1885)\end{array}$ \\
\hline Marital status3 & $\begin{array}{l}-0.0001 * * \\
(0.0010) \\
\end{array}$ & $\begin{array}{l}0.9988 * * * * \\
(0.0376) \\
\end{array}$ & $\begin{array}{l}-0.0001 * \\
(0.0001) \\
\end{array}$ & $\begin{array}{l}-0.1164 \\
(0.1164)\end{array}$ & $\begin{array}{l}-0.044 * * \\
(0.0475)\end{array}$ & $\begin{array}{l}0.1602 \\
(0.3419)\end{array}$ & $\begin{array}{l}0.4330 \\
(0.1885)\end{array}$ \\
\hline \multicolumn{8}{|c|}{ Identification variables that affect selection and Education but not health } \\
\hline $\begin{array}{l}\begin{array}{l}\text { Distance } \\
\text { drinking } \\
\text { source }\end{array} \\
\text { water } \\
\end{array}$ & & $\begin{array}{l}0.00004^{*} * * \\
\left(3.71^{\mathrm{e}}-06\right)\end{array}$ & & $\begin{array}{l}0.0011 \\
\left(8.71^{\mathrm{e}}-06\right)\end{array}$ & & & \\
\hline $\begin{array}{l}\begin{array}{l}\text { Time to } \\
\text { drinking } \\
\text { source }\end{array} \\
\text { water }\end{array}$ & & $\begin{array}{l}0.00002 * * \\
\left(4.29^{\mathrm{e}}-06\right)\end{array}$ & & $\begin{array}{l}0.00011 * * \\
\left(3.79^{\mathrm{e}}-06\right)\end{array}$ & & & \\
\hline $\begin{array}{l}\text { Owns the land } \\
\text { cultivated (yes = } \\
1,0 \text { otherwise) }\end{array}$ & & $\begin{array}{l}-0.0002 \\
(0.0001)\end{array}$ & & $\begin{array}{l}0.0007 * * * \\
(0.00015)\end{array}$ & & & \\
\hline $\begin{array}{l}\text { Type of latrine } \\
\text { used (improved = } \\
1,0 \text { otherwise) }\end{array}$ & & $\begin{array}{l}0.0282 \\
(0.0515)\end{array}$ & & $\begin{array}{l}-0.1006 \\
(0.0739)\end{array}$ & & & \\
\hline $\begin{array}{l}\text { Shares toilets (yes } \\
=1,0 \text { otherwise) }\end{array}$ & & $\begin{array}{l}0.3813^{* * * *} \\
(0.0728)\end{array}$ & & $\begin{array}{l}0.6351 * * * \\
(0.0066)\end{array}$ & & & \\
\hline \multicolumn{8}{|c|}{$\begin{array}{l}\text { Control function variables (account for } \mathrm{H} \text { effects of un-observables in the error term of the projected endogenous } \\
\text { variables) }\end{array}$} \\
\hline $\begin{array}{ll}\text { Predicted } & \text { HHE } \\
\text { residual }\end{array}$ & & & & & & $\begin{array}{l}-0.3828 * * \\
(0.1458)\end{array}$ & $\begin{array}{ll}-0.3964 \\
(0.1627)\end{array}$ \\
\hline $\begin{array}{l}\text { Interaction-HHE } \\
\text { and its residuals }\end{array}$ & & & & & & & $\begin{array}{l}0.0388 \\
(0.1419)\end{array}$ \\
\hline $\begin{array}{l}\text { Inverse of MILLS } \\
\text { Ratio }\end{array}$ & & $\begin{array}{l}-6.3427^{* * *} \\
(0.0281)\end{array}$ & & & & $\begin{array}{l}0.3454 \\
(0.2275)\end{array}$ & $\begin{array}{l}0.4029 \\
(0.3680)\end{array}$ \\
\hline Constant & $\begin{array}{c}-0.0547 \\
(0.2110)\end{array}$ & $\begin{array}{l}1.5059 \\
(0.3591)\end{array}$ & & $\begin{array}{l}0.3645 \\
(0.2720)\end{array}$ & $\begin{array}{ll}-0.098 \\
(0.3729)\end{array}$ & $\begin{array}{l}0.2450 \\
(0.2709)\end{array}$ & $\begin{array}{l}0.2099 \\
(0.3216)\end{array}$ \\
\hline $\begin{array}{l}\text { Number } \\
\text { Observations }\end{array}$ & 7502 & 6644 & & 6645 & 3341 & 3341 & 3341 \\
\hline $\begin{array}{l}\text { Censored } \\
\text { observations }\end{array}$ & & 3282 & & & & & \\
\hline $\begin{array}{l}\text { Wald ch2 (df; } \\
\text { p-value) }\end{array}$ & $\begin{array}{l}43.96 \\
(8 ; 0.000) \\
\end{array}$ & $\begin{array}{l}232.13 \\
(7 ; 0.000) \\
\end{array}$ & & $\begin{array}{l}387.22 \\
(8 ; 0.000) \\
\end{array}$ & $\begin{array}{l}447.49 \\
(4 ; 0.000)\end{array}$ & & \\
\hline $\begin{array}{ll}\text { LR test } & \text { of } \\
\text { independent } \\
\text { Equations } \\
\text { (df; p-value) }\end{array}$ & & $523.50(1 ; 0$. & & & & & \\
\hline \multicolumn{8}{|c|}{ Test of joint significance of identifying variables/Test of over identifying restrictions/Test all instruments } \\
\hline $\begin{array}{l}\text { Hansen' } \\
\text { statistics } \\
\text { p-value) }\end{array}$ & & & & 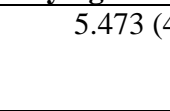 & $0.2420)$ & & \\
\hline
\end{tabular}

Source: The authors, using INS (2012) data set, and STATA 9.1 software. *,**, *** indicate 1 percent, 5 percent, and 10 percent levels of significance, respectively. ( ) under figures indicate t-ratios. 
Let's notice that the coefficient on literacy in Equation $(15),(\gamma)$, obtained from the non-linear control function estimates (Column 7), (-0.4288), is negative and significant at 10 percent level (t-ratio $=0.0217)$. These results are probably indicating that the spill-over effect of education on health is positive. Increasing the household head's education capital increases odds that the number of cases of sickness found in the household would diminish, and improve the household health. Likewise, the coefficient associated to the household head's sex $(-0.0355)$, like the one attached to the household head's age (-0.0064), are negative and significant at 10 percent and 5 percent levels, respectively. These findings may be indicating that in the households headed by males or by older persons, there are high chances of recording a low number of sick household members. It maybe that, in rural Cameroon, men and mature households' heads seem prompt to adopt more responsible and less risky health behaviors. In fact, they are probably aware of the fact that, given their low living standard, one more case of sickness could be dramatic for the whole family. This subject could be investigated in a future work.

Contrarily, the results coming from the same Table 3 show that household's size and household's head marital status2 (being single or divorced) appear to be two other significant health risk factors, since the coefficients attached to those variables are positive and significant. Particularly, there seems to be a tradeoff relation between household health and household size in rural Cameroon. In effect, preliminary data presented in the introduction of this study, tended to show that poverty has been gaining ground in rural Cameroun since 2001. In this context, it is not easy for poor rural households' heads to purchase enough health inputs in order to effectively take care of their large household members' health. Now, it is in the rural regions of Cameroon that household size is the highest and the living conditions toughest (INS, 2015b).

Results reported on Table 3 (Column 7), seem consistent. In particular, the complementary hypothesis is validated given the negative sign of $\gamma$. Thus, the illiterate rural dwellers could see their health be improved through not only education, but also through other channels that are not integrated into the non-linear control function estimated in column (7) of Table 3. Among these channels could be improved sanitation equipment and potable water source, quality housing, access to quality health facilities, better roads. Likewise, household head's sex and age could significantly contribute to improving the households' health as already noticed.

The Wald, LR, and Hansen tests results seem to indicate that our results are robust. In particular, all the Wald and LR tests statistics are significant. Furthermore, the constant of the non-linear health control function is not significant. In short, our findings corroborate those found in previous studies carried out namely by Baye and Fambon (2010), Zheng (2016), etc., and contradict those found recently by Heckman et al; (2016), Malamud et al; (2018), etc. Then, it seems that, in rural Cameroon, taken alone, household education will not necessary be enough to promote or foster the households' health.

Table 4. Estimation of the household economic well-being production function (OLS)

\begin{tabular}{|l|l|}
\hline Independent variables & Dependent variable: Household economic wellbeing (ECW) \\
\hline Predicted household health from control function & $-9.36 \mathrm{e}-16^{* *}$ \\
& $(4.38 \mathrm{e}-16)$ \\
\hline Household head's education1 & -0.0696 \\
& $(0.1746)$ \\
\hline Household head's education2 & $0.0169^{* * *}$ \\
& $(0.0197)$ \\
\hline Household head's education3 & $0.0648^{* * *}$ \\
& $(0.0248)$ \\
\hline Household head's education4 & $0.2309^{* * *}$ \\
& $(0.0360)$ \\
\hline Household head's sex & $0.0127^{* *}$ \\
& $(0.0017)$ \\
\hline Household size & $0.0077^{*}$ \\
& $(0.0003)$ \\
\hline Constant & $11.6415^{* * *}$ \\
\hline Number of observations & $(0.0197)$ \\
\hline Fischer statistics (degree freedom, p-value) & 5,744 \\
\hline R squared & $237.67(7 ; 0.000)$ \\
\hline Adjusted R squared & 0.22226 \\
\hline Roots MSE & 0.2217 \\
\hline
\end{tabular}

Source: The authors, using INS (2012) data set, and Stat 9.1 software. $*, * *$, and $* * *$ indicate 1 percent, 5 percent, and 10 percent significance levels, respectively. ( ) under figures indicate standard deviation. 


\subsection{Estimates of the Household Economic Wellbeing Production Function}

Table 4 presents the household economic wellbeing production function estimates. Contrary to the definition of education adopted previously (literacy), education refers to the level of school attended by the household head (defined in Table 1). Information coming from Table 4 show that coefficients associated with the right hand side variables are significant, except for the variable "household head's education1" (the household has never enrolled in any education level). These results seem to indicate that uneducated households' heads may find it more difficult to improve the economic wellbeing of their members, than educated households' heads.

More interestingly, it seems that the higher the household head's education level, the higher the household economic wellbeing. In fact, the coefficient associated with "higher education" is higher than the triple of that associated with that of the "secondary high education", for instance. These results tend to challenge those found in the literature, namely by Psacharopoulos (1994) and Pritchett (1996). Our findings seem consistent in the context of Cameroon, a country where salaries, specifically in the public sector, are determined according to the education level, and the salaried employees conditions are better than those of independent workers mostly found in the informal sector.

\subsection{Joint Effects of Education and Health on Economic Wellbeing}

Let's come back to the results reported on Table 4. Before diving into the Table, let's recall here that we are using predicted household health $(\dot{H})$ instead of observed household health $(H)$ in order to resolve the potential endogeneity of household health in the household economic wellbeing function. The coefficient attached to the predicted health from control function is negative and significant. This means that, like in the household health production function, the economic wellbeing may be improved with a relative weak level of the household head's education. Anyhow, our results may be indicating that health and education seem not to be perfectly substitutable in the household utility function.

In effect, being educated specially in the Cameroonian context, is not a necessary and sufficient condition of better individual or family wellbeing. An individual holding a high degree may not find a rewarding job in terms of high salary; he may simply be unemployed and be living at the family's expenses who may have spent a huge bundle of resources for his education. The family or household wellbeing will deteriorate more, particularly in the case where the graduated and unemployed individual is taken ill. To sum up, it seems logic and consistent to strongly contend that education has to be combined with many other inputs, of which health, to yield useful output in terms of economic wellbeing.

\section{Conclusion}

At the beginning of this paper, our objective was three-fold: (i) establishing a link between household education and household health, (ii) linking household education to household standard of living, and (iii) deducing the estimates of the combined effect of education and health on the household economic wellbeing. A structural model of household health demand for rural Cameroon has been estimated using data coming from the 2011 Health and demographic Survey (HDS). Household health was captured by the number of the household members who felt sick, were sick or sustained an injury 30 days before the survey. Two alternative measures of education was utilized, literacy and school attendance. A series of econometric estimation methods were used and the non-linear control function approach appeared to be the most appropriate since it purges the structural parameters of endogeneity, non-randomness of sample selection, and un-observed factors, concurrently.

In fact, empirical results show that using the likelihood, the generalized maximum or the linear control function estimation methods yields un-expected results that household head's education has a negative effect on household health. Thus, the non-linear control function method has been privileged and the results reached at seem consistent with those generally found in the literature on the complementary hypothesis. This finding may be suggesting that an educated household head will earn high salary, be in the position of buying more health and non-health inputs, and effectively caring on the rest of the household members' health.

The non-linear control function method yielded also some results indicating that the household size and being a widow could be two household health risks factors, even with a literate or educated household head. One guess here that the family health may be depending on factors beyond the control of the household head. In rural areas of Cameroon, the negative impact of factors such as poor roads, rare or poor equipped health facilities, absence of specialized physicians, and the like, may overtake the impact of education on health.

As for the effect of education on economic wellbeing, our findings seem to be in contradiction with some results found in the literature, namely by (Psacharopoulos, 1994; Pritchett, 1996). In fact, our results tend to show that the household economic wellbeing grows with the household head's education. In other words, education seems 
to exert a significant and positive influence on the household standard of living captured by the economic wellbeing index. The interaction of education and health appears to be negative, confirming the complementary hypothesis.

With regard to our findings, one may contend that consistent education policies may not be enough to improve the households' health. Furthermore, having quality education and health systems have to be complemented with other sound public polices in order to attain the objective of improving the households' social and economic wellbeing in rural Cameroon.

\section{References}

Adams, S. J. (2002). Education attainment and health: Evidence from a sample of older adults. Education Economics, 10(1), 97-109. https://doi.org/10.1080/09645290110110227

African Development Bank (ADB). (2019). African statistical yearbook 2019, ECA Printing and Publishing Unit, Addis Ababa, Ethiopia.

Ajakaiye, O., \& Mwabu, G. (2007, October). The demand for reproductive health services: An application of control function approach, Paper Presented in the Reproductive Health, Economic Growth and Poverty Reduction Capacity Building Workshop, Organized by AERC, in Abuja, Nigeria.

Ali, H. A., \& Grabowski, R. (1990). Education and child mortality in Egypt. World Development, 18(5), 733-742. https://doi.org/10.1016/0305-750X (90)90021-O

American Public Health Association (APHA). (2018). School-based health centers: Improving health, well-Being, and educational success. The School-Based Health Center Brief, February, 8 pages.

Anttila-Hughes, J. K., Lia C. H., Fernald, P. J., Gertler, K. P., \& Wydick, B. (2018). Mortality from Nestlé's marketing of infant formula in low and middle-income countries. NBER Working Paper No. 24452, Massachusetts, Cambridge. https://doi.org/10.3386/w24452

Arkes, J. (2003). Does schooling improve adult health? RAD Working Paper, Santa Monica. CA.

Aslam, M., \& Kingdon, G. (2010). Parental education and child health-understanding the pathways of impact in Pakistan. CSAE Working Papers 2010-16, 42 pages.

Barrow, L., \& Malamud, O. (2015). Is college a worthwhile investment? The Annual Review of economics, 7 , 519-555. https://doi.org/10.1146/annurev-economics-080614-115510

Baye, M. F., \& Fambon, S. (2009, March). Linking parental education, child health and standard of living in Cameroon, Paper presented at the CSAE Conference, at St Catherine's College, Oxford.

Baye, F. M., \& Fambon, S. (2010). Parental literacy and child health production in Cameroon. African Journal of Economic Policy, 17(2), 99-130.

Behrman, J. R. (1996). Impact of health and nutrition on education. The World Bank Research Observer, 11(1), February, 23-37. https://doi.org/10.1093/wbro/11.1.23

Bleakly, A., Costa, D., \& Lleras-Muney, A. (2013). Health, education and income in the United States, 1820 2000. NBER working paper 19162, NBER, Massachusetts, Cambridge. https://doi.org/10.3386/w19162

Bukles, K., Hagemann A., Malamud, O., Morrill, M. S., \& Wozniak, A. K. (2013). The effect of college education on health. NBER Working Paper No. 1922, NBER, Massachusetts, Cambridge, July.

Card, D. (2001). Estimating the return to birthweight. Review of Economics and Statistics, 86(2), 586-601. https://doi.org/10.1162/003465304323031139

Cesur, R., Dursun, B., \& Mocan, N. (2014). The impact of education on health and health behavior in a middle-income, low education country. NBER, Working Paper 20764, Massachusetts, Cambridge. https://doi.org/10.3386/w20764

Clark, D., \& Royer, H. (2010). The effect of education on adult health and mortality: Evidence from Britain. NBER Working Paper 16013, Massachusetts Avenue, Cambridge. https://doi.org/10.3386/w16013

Conti, G., Heckman, J., \& Urzua, S., (2010). The education-health gradient. American Economic Review: Papers \& Proceedings, (100), May, 234-238. https://doi.org/10.1257/aer.100.2.234

Corman, H., N. E. Dave, N. E., \& Reichman, N. E. (2017). Evolution of the infant health production function. NBER Working Paper 24131, December, Massachusetts Avenue, Cambridge.

https://doi.org/10.3386/w24131 
Culyer, A. J., \& Newhouse, J. (Eds.). (2000). Handbook of health economics, Vol. 1A and 1B. Amsterdam: North Holland. https://doi.org/10.1016/S1574-0064(00)80028-1

Curtler, M. D., \& Lleras-Muney, A. (2006). Education and health: Evaluating theories and evidence. NBER Working Paper 12352, Massachusetts, Cambridge. https://doi.org/10.3386/w12352

David, M. C., \& Adriana, L. M. (2010a). Understanding differences in health behaviors by education. Journal of Health Economics, 29(1), 29-38. https://doi.org/10.1016/j.jhealeco.2009.10.003

David, M. C., \& Adriana, L. M. (2010b). The education gradient in old age disability. In David Wise (Ed.), Research Findings in the Economic of Aging, Chicago: University of Chicago Press: 101-120. https://doi.org/10.7208/chicago/9780226903088.003.0005

David, M. C., \& Adriana, L. M. (2012). Education and health: Insights from International Comparison. NBER Working Paper 17738, Massachusetts, Cambridge. https://doi.org/10.3386/w17738

Doepke, M., Sorrenti, G., \& Zilibotti, F. (2019). Economics of parenting. Working Paper 25533, National Bureau of Economic Research 1050, Massachusetts Avenue, Cambridge, MA 02138. https://doi.org/10.3386/w25533

Gan, L., \& Gong, G. (2007). Estimating interdependence between health and education in a dynamic model, NBER Working Paper 19162, Massachusetts, Cambridge. https://doi.org/10.3386/w12830

Garen, P. (1984). The returns to schooling: A selectivity bias approach with continuous choice variable, Econometrica, 52(5), 1199-1218. https://doi.org/10.2307/1910996

Grossman, M. (1982). The demand for health after a decade, Journal of Health Economics, 1, 1-3. https://doi.org/10.1016/0167-6296(82)90018-2

Michael, G. (2005). Education and non-market outcomes. NBER Working Paper 11582, Massachusetts, Cambridge. https://doi.org/10.3386/w11582

Michael, G. (2008). The relationship between health and schooling: Presidential address. Eastern Economic Journal, 34(3), 281- 292. https://doi.org/10.1057/eej.2008.13

Michael, G., \& Joyce, T. J. (1990). Un-observables, pregnancy resolutions, and birth weight production function in New York City. Journal of Political Economy, 98(5), 983-1007. https://doi.org/10.1086/261716

Handa, S. (1999). Maternal education and child height. Economic Development and Cultural Change, 47(2), 421-439. https://doi.org/10.1086/452408

Hansen, L. (1982). Large sample properties of generalized method of moments estimators. Econometrica, 50(3), 1029-1054. https://doi.org/10.2307/1912775

Heckman, J. J. (1976). The common structure of statistical models of truncation, sample selection, and limited dependent variables and simple estimator for such models. Annals of Economic and Social Measurement, 5, 475-92.

Heckman, J. J. (1979). Sample selection bias as a specification error. Econometrica, 47(1), 153-162. https://doi.org/10.2307/1912352

Heckman, J. J., Humphries, J. E., Veramendi, G., \& Urzúa, S. (2014). Education, health and wages. NBER Working Papers 19971, Massachusetts, Cambridge. https://doi.org/10.3386/w19971

Heckman, J. J., Humphries, J. E., \& Veramendi, G. (2016). Returns to education: The causal effects of education on earning, health and smoking, Iza Discussion Paper No. 9957, May, 66 pages. https://doi.org/10.3386/w22291

Heller, P. S. (1982). A model of the demand for medical and health services in Peninsular Malaysia, Social Science and Medicine, 16, 267-284. https://doi.org/10.1016/0277-9536(82)90337-9

Huang, W. (2015). Understanding the effects of education on health: Evidence from China. IZA Discussion Paper No. 9225. Harvard University.

International Monetary Fund. (2014). World Economic Outlook.

Institut National de la Statistique (INS). (2012). Enquête démographique et de santé et à indicateurs multiples (EDS-MICS).

Institut National de la Statistique. (2015a). Enquête par grappes à indicateurs multiples (MICS5) 2014. Yaoundé, Cameroun, Institut National de la Statistique. 
Institut National de la Statistique. (2015b). Enquête camerounaise auprès des ménages (ECAM4) 2014. Rapport final, Yaoundé, Cameroun, Institut National de la Statistique.

Joyce, T. J. (1994). Self-selection, prenatal care, and birth weight among Blacks, Whites, and Hispanics in New York City, Journal of Human Resources, 29(3), 947-87. https://doi.org/10.2307/146252

Lleras-Muney, A. (2005). The relationship between education and adult mortality in the United States, Review of Economic Studies, 72(1), 189-221. https://doi.org/10.1111/0034-6527.00329

Malamud, O., Mitrut, A., \& Pop-Eleches, C. (2018). The effect of education on mortality and health: Evidence from a schooling expansion in Romania. NBER Working paper 24341, Massachusetts, Cambridge. https://doi.org/10.3386/w24341

Meghir, C., Palme, M., \& Simeonova, E. (2013). Education, cognition and health: Evidence $\quad$ from social experiment. NBER Working Paper 19002, Massachusetts, Cambridge. https://doi.org/10.3386/w19002

Ministère de l'Eau et de l'Energie (MINEE). (2013). 'Etude sur la stratégie d'assainissement en milieu rural'. Yaoundé, Cameroun, MINEE.

Ministère de la santé publique (MINSANTE. (2018). Plan national de développement sanitaire (PNDS) 2016 - 2010. Yaoundé, Cameroun, MINSANTE.

Mwabu, G. (2009). The production of child health in Kenya: A structural model of birth weight. Journal of African Economies, 18(2), 212-286. https://doi.org/10.1093/jae/ejn013

Ogunleye, E. K., \& Eris, B. (2008). A human capital and economic growth: Comparative analysis of the impact of knowledge and health on economic growth in Nigeria and Turkey. The Journal of Knowledge Economy \& Knowledge Management, 3, Spring, 109-126.

Pritchett, L. (1996). Where has all the education gone? World Bank Policy Research Working Paper, 1581, World Bank, Washington DC.

Psacharopoulos, G. (1994). Returns to investment in education: A global update. World Development, 22(9), 1325-1343. https://doi.org/10.1016/0305-750X(94)90007-8

Robert Wood Johnson Foundation, Health Policy Snapshot. (2013). Why does education matter so much to health? Issue Brief, March.

Rosenzweig, M. R., \& Schultz, T. P. (1989). Schooling, information and nonmarket productivity: Contraceptive use and its effectiveness. International Economic Review, 30(2), 457-77. https://doi.org/10.2307/2526657

Rosenzweig, M. R., \& Zhang, J. (2006). Do population control policies induce more human capital? Twins, birthweight, and China's 'one child policy'. Discussion Paper, Economic Growth Centre, Yale University.

Strauss, J., \& Thomas, D. (1998). Health, nutrition, and economic development. Journal of Economic Literature, 36(2), June, 766-817.

Tambi, M. D., Njong, A. M., \& Baye, F. M. (2014). Linking child health, maternal labor force participation and household asset endowments in Cameroon: What the people say. Russian Journal of Agricultural and Socio-Economic Sciences, 10(3), 3-17. https://doi.org/10.18551/rjoas.2014-10.01

United Nations. (2019). The sustainable development goals report 2019, United Nations, New York.

Walker, S. P., Chang, S. M., Powell, C. A., \& Grantham-McGregor, S. M. (2005). Effects of early childhood psychosocial stimulation and nutritional supplementation on cognition and education in growth-stunted Jamaican children: prospective cohort study. Lancet, 366(9499), 1804-7. https://doi.org/10.1016/S0140-6736(05)67574-5

Woodridge, J. M. (1997). On two stage least squares estimation of the average treatment effect in a random coefficient model, Economic Letters, 56, 129-133. https://doi.org/10.1016/S0165-1765(97)81890-3

Woodridge, J. M. (2002). Econometric analysis of cross section and panel data. The MIT Press, Cambridge, Massachusetts, London, England.

Woolf, S. H., Aron, L., Dubay, L., Simon, S. H., Zimmerman, E., \& Luk, K. X. (2015). How are income and wealth linked to health and longevity? Income and Health Initiative: Brief one, Center on Society and Health, Urban Institute and Virginia Commonwealth University, 22 pages.

World Bank. (2017). World development indicators 2017. The World Bank, Washington.

World Health Organization (WHO). (2001). World health report 2001. World Health Organization, Geneva. 
World Health Organization (WHO). (2019). World health statistics 2019. Monitoring health for SDGs, sustainable development goals. World Health Organization, Geneva.

Zheng, H. (2016). Why college education matters? Understanding the contribution of selection factors. Social Sciences Research, 68, 59-73. https://doi.org/10.1016/j.ssresearch.2017.09.003

\section{Copyrights}

Copyright for this article is retained by the author(s), with first publication rights granted to the journal.

This is an open-access article distributed under the terms and conditions of the Creative Commons Attribution license (http://creativecommons.org/licenses/by/4.0/). 